\title{
Recovering energy from liquid sanitary waste through direct alcohol fuel cells
}

\author{
V. Pelillo \& D. Laforgia \\ University of Salento, Italy
}

\begin{abstract}
The evolution of energy systems can take place through different ways and, sometimes, by using processes already known but needing to be improved by continuous research and development. This is the case of direct alcohol fuel cell (DAFC), known since a century ago, but whose operating mode consists of employing (under specified conditions) alcohol. The objective of this work is not only to show the sustainability of these devices but mainly their application for supplying re-cycled ethanol and glycol, recovered from sanitary liquid wastes, to be used for biomedical apparatuses and plant located inside hospital pavilions, such as neonatology, resuscitation and surgery rooms, where, electric energy must not be interruptible for safety reasons and, as a consequence, DAFC must always be working. The proposed solution is supported by the U.E. Act (Directive $2006 / 12 / C E$ ) that allows waste recovery in order to produce energy. It is an innovating and alternative manner to provide a good use of sanitary liquid wastes instead of sending them to common and regular disposal.
\end{abstract}

Keywords: sanitary wastes, cell fuel, disposal, waste recovery, waste legislation.

\section{Introduction}

Hospital or clinical or sanitary wastes require particular management procedures different from those applied to general wastes. There are specific classifications according to each western country's legislation. They include not only the so-called conventional wastes but also the so-called unconventional ones, that is, radioactive wastes. To dispose these wastes, the main technique consists of using appropriate incineration plants capable of achieving the task in a way such that the environment is protected. Various studies suggest that as much as $50 \%$ of waste sent for incineration as clinical waste is in fact general waste, leading to 
unnecessarily high disposal costs [1]. Improved segregation can generate substantial savings. In an ideal world, segregation of waste should take place at the point of production, for example, on the wards or in operating rooms. Encouraging segregation at production sites may help to save money and provide a secure and correct way of disposing hazardous materials in order to prevent irreversible damage to the environment. For the purposes of this research, the acceptation sanitary waste is used because it includes any waste produced by any establishment where health activities are operated for the interest of humans and animals. However, the meaning of acceptations hospital and clinical waste could be a little bit confusing. Firstly, it is helpful to recall the origin of sanitary wastes and their contents. Sanitary wastes come from various sources such as private and public hospitals, health centers, research facilities, health laboratories, veterinary surgeries and dental surgeries [2]. Moreover, the contents consist wholly and partly of various items such as syringes, needles, glasses, human or animal tissue, swabs, dressings, excretions, blood, physiological fluids, pharmaceutical wastes and incontinence bags [3]. Sanitary liquids play a key role in a hospital, especially if they contain solvents that could be extracted in order to be regenerated for recycling in a new process. Improving the mechanism of waste segregation means money savings and keeping the environment safe. Different western countries, before the introduction of new regulations, namely the European Waste Code (EWC) in its diverse versions, have faced in many ways sanitary waste issues. The increasing costs and technology development may impose a new vision and a new approach to the search for ways to segregate waste in the hospital facilities. This segregation must be enhanced especially by separating liquids from solids, hazardous from non-hazardous, flammable from inflammable. The UK [4], France [5] and Italy [6], for example, regulated, in an appropriate way, the matter in the 90 s by distinguishing between the types of sanitary waste as well as the procedures for final disposal according to WHO [7].

There has been an underlying disparity across Europe in the approach to the management of sanitary wastes, both within hospitals [8] and in the commercial sector. Differences have been harmonized by the European Hazardous Waste Directive 91/689/EC (HWD), which seeks to provide a precise and uniform European-wide definition of hazardous wastes, including clinical wastes, and to ensure its regulation and correct management. The classification of a waste as hazardous has considerable impact in determining how that waste is regulated, and thereby on the care required at all stages from initial disposal to final destruction. A detailed classification of wastes is set out in the European Waste Catalogue 2000/532/EC (EWC), an essential first step in the implementation of the HWD. EWC classification permits down-regulation of some clinical wastes. The EWC is pivotal to this legislation, enabling classification of wastes based upon composition and hazard (table 1). Non-hazardous wastes escape stringent control in disposal that had previously been applied in blanket fashion, permitting correspondingly lower disposal costs. 
Table 1: $\quad$ European Waste Catalogue (2002) categorization of some sanitary wastes.

\begin{tabular}{|c|c|}
\hline 18 & $\begin{array}{l}\text { Wastes from human and animal health care and/or related research (except kitchen and } \\
\text { restaurant wastes not arising from immediate health care) }\end{array}$ \\
\hline 1801 & $\begin{array}{l}\text { Wastes from natal care, diagnosis, treatment or prevention of } \\
\text { disease in humans }\end{array}$ \\
\hline 180101 & Sharps (except 180103 ) \\
\hline 180102 & $\begin{array}{l}\text { Body parts and organs including blood bags and blood preserves } \\
\text { (except } 180103 \text { ) }\end{array}$ \\
\hline $180103^{*}$ & $\begin{array}{l}\text { Wastes whose collection and disposal is subject to special } \\
\text { requirements in order to prevent infection }\end{array}$ \\
\hline 180104 & $\begin{array}{l}\text { Wastes whose collection and disposal is not subject to special } \\
\text { requirements in order to prevent infection (e.g. dressings, plaster } \\
\text { casts, linen, disposable clothing, nappies) }\end{array}$ \\
\hline $180106^{*}$ & Chemicals consisting of or containing dangerous substances \\
\hline 180107 & Chemicals other than those mentioned in 180106 \\
\hline $180108^{*}$ & Cytotoxic and cytostatic medicines \\
\hline 180109 & Medicines other than those mentioned in 180108 \\
\hline $180110^{*}$ & Amalgam waste from dental care \\
\hline
\end{tabular}

Any waste whose six-digit code is marked with an asterisk (*) is a hazardous waste. Classification may be absolute (A), defining waste as hazardous regardless of the concentration of any 'dangerous substance' within it, or a 'mirror entry' ( $M$ ), covering wastes having the potential to be hazardous or non-hazardous depending on their composition and the concentration of 'dangerous substances' within them. The hazard potential is determined by reference to published threshold limits or, for infection hazards, on risk assessment.

\section{Direct alcohol fuel cell}

Fuel cells generate electric power from an electrochemical process using fuels such as hydrogen or methanol. Compared with batteries, fuel cells typically have a higher energy density and a lower weight. In addition, fuel cells are environmentfriendly (especially if the fuel is taken from a renewable resource) and can be recharged instantly. Fuel cells are being used in prototype applications to power vehicles, cellular telephones, homes, commercial properties, laptops, household appliances and industrial machinery. A direct alcohol fuel cell (DAFC) uses liquid alcohols as a fuel and is very attractive as power source for mobile, stationary and portable applications. However, alcohols are very difficult to electro-oxidize completely and up to now methanol has been considered the most promising organic fuel. Carbon-supported $\mathrm{PtRu}$ nanoparticles $(\mathrm{PtRu} / \mathrm{C})$ are the best electrocatalysts for direct methanol fuel cell (DMFC), however, the synthesis of highly dispersed carbon supported PtRu nanoparticles with high loading remains a challenge. The conventional methods of preparation, like wet impregnation and reduction, do not provide satisfactory control of the particle size and distribution.

\section{Waste segregation and recovery for DAFC supply}

Further segregation is proposed as an effective method of reducing costs in waste disposal, and for achieving compliance with the new legislative controls that prohibit mixing of wastes [9]. Directed principally at the elimination of packaging wastes from the more costly sanitary waste stream, space constraints in clinical areas can present practical problems that limit the options for additional segregation. Though attractive on environmental, ecological and administrative grounds, such complex and comprehensive waste management procedures are 
likely to succeed only in newly-build hospitals where sufficient space is devoted to these core functions at the design and construction stages. Since space is at a premium in the majority of existing building stock, the elimination of packaging waste from clinical wastes might best be achieved by removal at source, in the supply department, though this requires care to protect the integrity of sterile supplies. In circumstances where segregation of wastes is undertaken solely at the point of arising, in the busy and often cramped hospital ward, the risks associated with incorrect segregation that might result in clinical wastes entering a more general domestic waste stream cannot be dismissed. Efficient supply chain management may thus offer an effective response to demands for the improved segregation of wastes, reducing costs without compromise of safety, and supporting effective risk reduction. However, based on the evidence reported here, it is apparent that there has been little if any improvement and that much still remains to be done to improve the standards of clinical waste management in hospitals.

Amid the aforementioned sanitary wastes, solvents containing alcohol are very interesting as fuel for DAFC. So, in hospital facilities, there is a need of creating specific areas for stocking wastes in a segregated way, especially for solvents containing alcohol (ethanol and ethylene glycol). This procedure would be permitted by some legislation, for instance, the European directive 2006/12/EC and the Italian one [10]. Ethanol and ethylene glycol are used in hospital facilities and they are good energetic vectors with respect to hydrogen and to hydrocarbons. They have a high solubility in water and energy density $(\mathrm{We})$ like gasoline $\left(10-11 \mathrm{kWh} \mathrm{kg}^{-1}\right)$ [11]. Moreover, since energy efficiency $\left(\varepsilon_{r}\right)$ of DAFC is greater than that of hydrogen/oxygen-based cell fuel (table 2), that is, $83 \%$ at $25^{\circ} \mathrm{C}$, this is the interesting reason for recovering ethanol and ethylene glycol from sanitary liquids for energetic objectives. Ethanol and ethylene glycol are good sources of energy, even if it is necessary for their electrochemical reaction to entail the increasing of anode overvoltage towards high values with respect to those reached by hydrogen (fig. 1). This inconvenience could be overcome by allowing the reaction to be performed on binary or ternary catalyzer based on platinum which allows the production of molecules with small dimensions that are easily oxidizable to $\mathrm{CO}_{2}[12]$.

Table 2: Thermodynamic data of related to electrochemical oxydation of some alcohols.

\begin{tabular}{llllllll}
\hline Fud & $\begin{array}{l}\Delta G \\
/ \mathrm{kJ} \mathrm{mol}^{-1}\end{array}$ & $\begin{array}{l}\mathrm{E}^{-} \\
/ \mathrm{V} \mathrm{vs} \mathrm{SHE}\end{array}$ & $\begin{array}{l}E_{\text {ent }} \\
/ \mathrm{V}\end{array}$ & $\begin{array}{l}\Delta G \\
/ \mathrm{kJ} \mathrm{mol}^{-1}\end{array}$ & $\begin{array}{l}W_{\mathrm{e}} \\
/ \mathrm{kWh} \mathrm{kg}^{-1}\end{array}$ & $\begin{array}{l}\Delta \mathrm{H} \\
/ \mathrm{kJ} \mathrm{mol}^{-1}\end{array}$ & $\varepsilon_{+}$ \\
\hline $\mathrm{CH}_{3} \mathrm{OH}$ & -9.3 & 0.016 & 1.213 & -702.7 & 6.09 & -726.7 & 0.967 \\
$\mathrm{C}_{2} \mathrm{H}_{5} \mathrm{OH}$ & -97.3 & 0.084 & 1.145 & -1326.7 & 8.01 & -1367.9 & 0.970 \\
$\mathrm{CH}_{2} \mathrm{OH}-\mathrm{CH}_{2} \mathrm{OH}$ & -4.8 & 0.005 & 1.224 & -1181.5 & 5.29 & -1190.2 & 0.992 \\
$\mathrm{C}_{3} \mathrm{H}_{3} \mathrm{OH}$ & -168 & 0.097 & 1.132 & -1965.3 & 9.10 & -2023.2 & 0.971 \\
$\mathrm{C}_{4} \mathrm{H}_{9} \mathrm{OH}$ & -243 & 0.105 & 1.124 & -2602.1 & 9.77 & -2676.8 & 0.972 \\
\hline
\end{tabular}




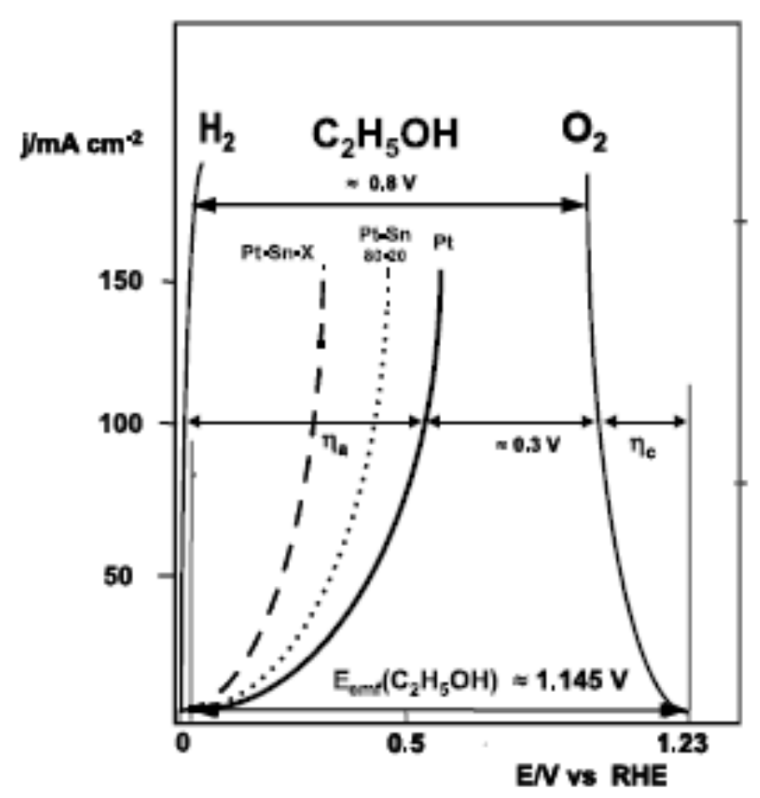

Figure 1: Comparison between voltage-current of a $\mathrm{H}_{2} / \mathrm{O}_{2}$-based cell fuel with platinum electrodes and DAFC ethanol with anodic ternary catalyzer (Pt-Sn-X).

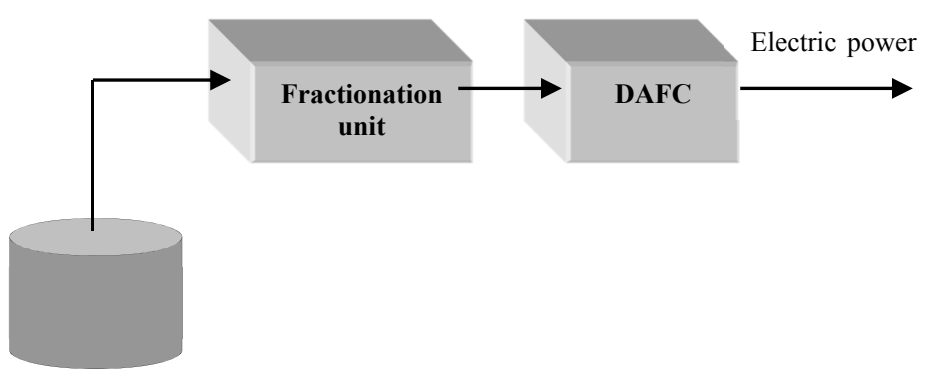

Figure 2: Block scheme of proposed architecture.

Fig. 2 illustrates the proposed architecture of processing segregated liquid wastes extracted from sanitary waste and from sanitary decayed radioactive wastes. Both types of waste, including other solvents that have not been segregated before, are stocked in a specific tank of fig. 2. Afterwards, the liquids are treated in a fractionation unit according to the plant of fig. 3 .

Thanks to Antoine equation [13], using the appropriate constants, it is possible to calculate the vapor tension of both alcohols (ethanol and ethylene glicol), then, their volatility and the relative one. 


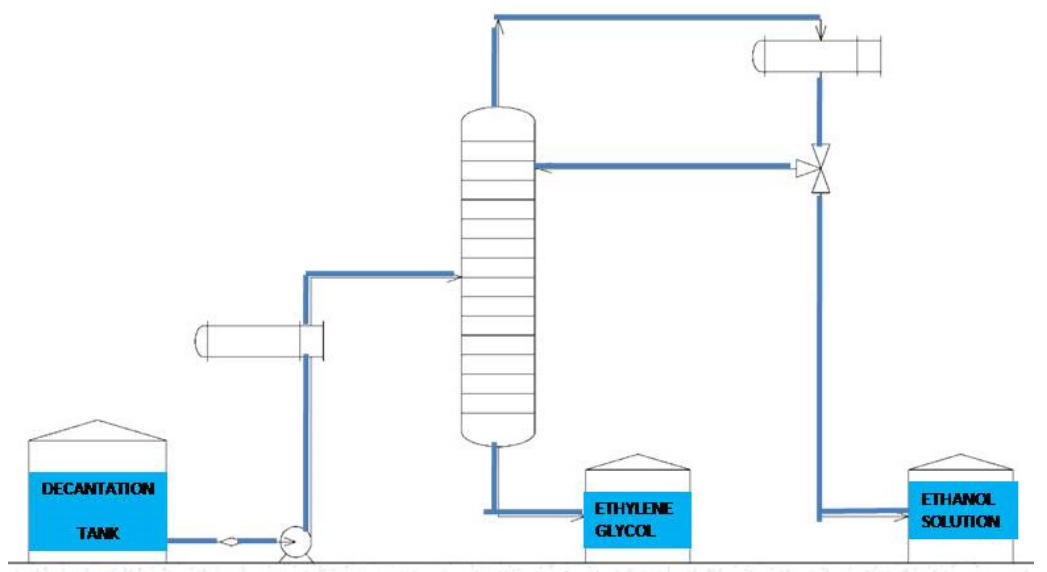

Figure 3: Fractionation plant/unit.

To calculate the number of steps necessary to obtain the destre separation, it is appropriate to use the FUG (Fenske-Underwood-Gilliland) method according to the following procedure:

$$
\begin{gathered}
N_{\text {min }}=\frac{\log \left(\frac{x_{D_{i}}}{x_{B_{i}}} \cdot \frac{x_{B_{j}}}{x_{D_{j}}}\right)}{\log \alpha^{*}} \\
1-q=\sum \frac{\alpha_{i} x_{F_{i}}}{\alpha_{i}-\Theta} \\
R_{\text {min }}+1=\sum \frac{a_{i} x_{D_{i}}}{a_{i}-Q} \\
\frac{N-N_{\text {min }}}{N+1}=1-\exp \left[\frac{(1+54.4 X)(X-1)}{(11+117.2 X) \sqrt{X}}\right]
\end{gathered}
$$

where $X$ is given by

$$
X=\frac{R-R_{\min }}{R+1}
$$

and all symbols are explained under Nomenclature. 
Finally, to establish in which stage it is better to feed, the Kirkbride equation has been used in an empirical way, that is,

$$
\frac{N_{R}}{N_{S}}=\left[\left(\frac{B}{D}\right)\left(\frac{x_{F, H K}}{x_{F, L K}}\right)\left(\frac{x_{B, L K}}{x_{D, H K}}\right)\right]^{0.206}
$$

The FUG method has allowed the determination of the following parameters for the design of the system:

$$
N_{\min }=2, R_{\min }=0.24, N=7, R=0.31 \text {, number of feeding stages }=5 .
$$

\section{Summary and conclusions}

This research has illustrated the opportunity of recovering alcohols from sanitary wastes in order to use them for feeding a DAFC. In general, even if a segregation is carried out in clinical and hospital facilities, solvents containing alcohols are used in these facilities for different reasons. But an over-segregation that allows the recovery of alcohols from conventional sanitary wastes and decayed radioactive ones will produce great benefits for saving money and protecting the environment. The use of DAFC fuelled by recovered alcohols is essential for hospital pavilions like neonatology, resuscitation and surgery rooms, where, the electric energy must not be interruptible for health and safety reasons. The proposed research agrees with European and national legislations.

\section{Nomenclature}

$\begin{array}{ll}B & \text { Residual flow in } \mathrm{kmol} / \mathrm{h} \\ D & \text { Residual flow in } \mathrm{kmol} / \mathrm{h} \\ F & \text { Flow for tower in } \mathrm{kmol} / \mathrm{h} \\ F_{w} & \text { Flow for fractionation tower in } \mathrm{kg} / \mathrm{h} \\ N & \text { Effective number of stage for separation } \\ N_{\text {min }} & \text { Minimal number of necessary stages for separation } \\ N_{R} & \text { Number of stages over feeding } \\ N_{S} & \text { Number of stages under feeding } \\ P & \text { Operating pressure } \\ P M_{\text {ethanol }} & \text { Ethanol molecular weight } \\ P M_{g l y c o l} & \text { Ethylene Glycol molecular weight } \\ P M_{\text {mix }} & \text { Mixed feeding molecular weight } \\ p^{\circ} & \text { Vapor tension } \\ R & \text { Reflux } \\ R_{\min } & \text { Minimal reflux } \\ T_{e b} & \text { Ebullition temperature } \\ x_{B} & \text { Fraction in moles of ethanol in residual } \\ x_{D} & \text { Fraction in moles of ethanol in the distilled } \\ x_{D w} & \text { Fraction in weight of ethanol in the distilled }\end{array}$




$\begin{array}{ll}x_{F} & \text { Fraction in moles of ethanol in the feeding } \\ x_{F w} & \text { Fraction in weight of ethanol } \\ \alpha & \text { Viscosity } \\ \alpha^{*} & \text { Relative viscosity }\end{array}$

\section{References}

[1] Mercier, C. \& Ellam, T., Waste disposal. Waste not, want not. Health Service Journal, 106(5497), p. 27, 1996.

[2] Department of the Environment, Transport and the Regions (DETR), A better quality of life: A strategy for sustainable development for the United Kingdom, HMSO: London, 1999.

[3] Health Services Advisory Committee (HSAC), Safe Disposal of Clinical Waste, 2nd ed., HSE Books, The Stationery Office, 1999.

[4] Audit Commission, 1997b, Pembrokeshire NHS Trust, 1996.

[5] Act of 13 July 1992.

[6] Italian act DPR 254/2003.

[7] Organisation Mondiale de la Santé, la gestion des déchets des hopitaux et autres établissements de soins de santé, Rapport sur une reunion de l'OMS, Bergen 28 juillet - 1 juin 1983, Danemark, ISBN 9289022639.

[8] Muhlich, M., Scherrer, M. \& Daschner, F.D., Comparison of infectious waste management in European hospitals. Journal of Hospital Infection, 55, pp. 260-268, 2003.

[9] Townend, W.K. \& Cheeseman, C.R., Guidelines for the evaluation and assessment of the sustainable use of resources and of wastes management at healthcare facilities. Waste Manage Research, 23, pp. 398-408, 2005.

[10] Italian act Dlgs.152/06 Parte IV, art.179 s.m.i.

[11] Lamy, C., Lima, A., LeRhun, V., Delime, F., Coutanceau, C. \& Léger, J.M., Recent advances in the development of direct alcohol fuel cells (DAFC). Journal of Power Sources, 105(2), pp. 283-296, 2002.

[12] Laborde, H., Rezzouk, A., Léger, J.-M. \& Lamy, C., Effect of the electrodestructure on the electrocatalytic oxidation of low-weight alcohols. Applications to the direct alcohol fuel cell. Proc. of the Symposium on Electrode Material and Processes for Energy Conversion and Storage, eds. S. Srinivasan, D.D. McDonald \& A.C. Khandkar, The Electrochemical Society, pp. 275-294, 1994.

[13] Sinnott, R.K., Coulson \& Richardson's Chemical Engineering, vol. 6: Chemical Engineering Design, $3^{\text {rd }}$ ed., Butterworth-Heinemann: Oxford, 2003. 